\title{
Działalność gospodarcza i kariera zawodowa a zaangażowanie w proces studiowania
}

\section{Business and Professional Career vs. Commitment to Studying}

Streszczenie: Artykuł podejmuje próbę sprawdzenia wybranych cech przedsiębiorczych wśród studentów w odniesieniu do ich zaangażowania w proces studiowania oraz potencjalnego zaangażowania jako pracowników. Głównym celem jest zweryfikowanie, na ile badani posiadają chęci do prowadzenia własnej działalności gospodarczej, oraz jaka jest ich świadomość związana z prowadzeniem takiej działalności. Badania ankietowe przeprowadzono na 138 studentach Wydziału Politologii Uniwersytetu Pedagogicznego im. KEN w Krakowie. Studenci biorący udział w badaniu zadeklarowali duże zaangażowanie w zdobywanie wiedzy oraz wysoko ocenili swoją komunikatywność. Nieco gorzej wypadają ich zaangażowanie w realizację dodatkowych przedsięwzięć oraz zdolności przywódcze. Stosunkowo spora grupa respondentów miała problem $\mathrm{z}$ określeniem swojego zaangażowania $\mathrm{w}$ studia. Badani studenci nie wykazywali skłonności do długiego dnia pracy, 98\% z nich uznało, że mogłoby pracować osiem lub mniej godzin dziennie. W przypadku choroby badani studenci wykazali się dość dużym poświęceniem, niemal połowa mogłaby dalej pracować, o ile choroba nie byłaby ciężka, natomiast $22 \%$ badanych uznało, że starałoby się pracować z domu. Niewielu badanych, bo 14\%, uznało, że nie będzie pracować na zwolnieniu lekarskim. Pytania zawarte $w$ ankiecie nie dotyczyły wprost posiadania cech przedsiębiorczych, jednak deklarowane postawy studentów można odnieść do ich predyspozycji przedsiębiorczych i gotowości do prowadzenia własnej działalności gospodarczej.

Abstract: The article attempts to check entrepreneurial attributes among students in relation to their
involvement in the process of studying and potential involvement as an employee. The main objective
is to verify to what extent the respondents have the appropriate characteristics to run their own business
and what their awareness is related to the realities of running such activities. Surveys were conducted
on 138 students of the Faculty of Political Sciences at the Pedagogical University of Cracow. Students
participating in the study declare a strong commitment to acquiring knowledge and highly assess their
communicativeness. Their involvement in the implementation of additional ventures and leadership
skills is slightly worse. Relatively large group of respondents have problems with defining their involve-
ment in studies. The surveyed students did not show a willingness to work for many hours, $98 \%$ of them
considered that they could work 8 or less hours a day. In the case of illness, the surveyed students showed
quite a large dedication, almost half are able to continue working, provided the disease is not severe,
while $22 \%$ of respondents felt that they would try to work from home. Only some respondents, $14 \%$, said 
they would not work on sick note. The questions contained in the questionnaire did not directly concern entrepreneurial characteristics, but the attitudes of students exhibited in the study can be referred to their entrepreneurial predispositions.

Słowa kluczowe: działalność gospodarcza; edukacja; postawy przedsiębiorcze; przedsiębiorczość

Key words: economic activity; education; entrepreneurial attitudes; entrepreneurship

Otrzymano: 19 listopada 2018

Received: 19 November 2018

Zaakceptowano: 26 lutego 2019

Accepted: 26 February 2019

\section{Sugerowana cytacja/Suggested citation:}

Maciejewski, W. (2019). Działalność gospodarcza i kariera zawodowa a zaangażowanie w proces studiowania. Przedsiębiorczość - Edukacja [Entrepreneurship - Education], 15(1), 113-125. doi: $10.24917 / 20833296.151 .9$

\section{Wstęp}

Absolwent uczelni wyższej powinien posiadać wiedzę, umiejętności i kompetencje pozwalające na wykonywanie pracy wymagającej odpowiedzialności, umiejętności podejmowania decyzji, umiejętności zarządzania zasobami ludzkimi, zarządzania ryzykiem i skutecznego działania w sytuacjach stresowych. Wymienione postawy odpowiadają częściowo postawom przedsiębiorczym, które okazują się użyteczne nie tylko w przypadku prowadzenia działalności gospodarczej. W artykule została podjęta próba zweryfikowania, na ile studenci wybranych kierunków studiów wykazują postawy przedsiębiorcze w odniesieniu do ich zaangażowania w proces studiowania oraz zaangażowania jako potencjalnych pracowników. Autor przyjął założenie, że zaangażowanie w studia, jako inwestycję we własny kapitał, może porównać do inwestycji we własne przedsiębiorstwo. Jednocześnie zaangażowanie $\mathrm{w}$ pracę może być porównywalne z zaangażowaniem $\mathrm{w}$ prowadzenie własnej działalności gospodarczej.

\section{Przedsiębiorczość i prowadzenie działalności gospodarczej}

Posiadanie cech przedsiębiorczych i umiejętności wykorzystywania szans, jakie stwarza kapitalizm, pozwalają na skuteczne zarządzanie własną firmą. Prowadzenie działalności gospodarczej umożliwia osiągnięcie sukcesu nie tylko w wymiarze ekonomicznym, ale również w wymiarze społecznym. Funkcjonujące w powszechnej opinii przekonanie o zamożności osób prowadzących działalność gospodarczą wynika często z bardzo ogólnikowych ocen. Wypracowanie wysokiego obrotu pieniężnego nie jest tożsame z wypracowaniem zysku i to przynajmniej jedna z przyczyn niepełnej oceny pracy przedsiębiorców. Termin „przedsiębiorczość” stał się bardzo popularny i jest coraz częściej powtarzany w kontekście: rozwoju gospodarczego, zmian gospodarczych, edukacji oraz $\mathrm{w}$ innych niezliczonych sytuacjach. Wynika to $\mathrm{z}$ jego niejednoznacznego rozumienia oraz interdyscyplinarności (Wach, 2015), a także z wpływu przedsiębiorczości na rozwój społeczno-ekonomiczny (Czarnecka, Kłodziński, 2010; Guerrero, Cunningham, Urbano, 2014; Maciejewski, Faron, 2014; Płaziak, Rachwał, 2015; Stel, Carree, Thurik, 2005; Zioło, 
2012, 2016). Przedsiębiorczość jest definiowana w wielu wymiarach i trudno podać jej konkretną definicję, która holistycznie ujmowałaby jej znaczenie. Bez względu jednak na teoretyczne rozważania związane z definiowaniem przedsiębiorczości, jej termin bardzo często jest kojarzony z prowadzeniem działalności gospodarczej. To powiązanie bardzo wyraźnie widać w najważniejszych atrybutach przedsiębiorczości (Gartner, 1990: 18), którymi są:

- działalność związana z rozpoczęciem własnej działalności gospodarczej,

- tworzenie nowego biznesu,

- innowacyjność,

- przejmowanie istniejącego przedsiębiorstwa,

- utworzenie innowacyjnego przedsięwzięcia w istniejącej organizacji,

- stworzenie organizacji non profit,

- stworzenie organizacji państwowej.

W wymienionych atrybutach dużą uwagę przywiązano do tworzenia przedsięwzięć gospodarczych i społecznych. Nie wyczerpują one wszystkich aspektów związanych z przedsiębiorczością i dotyczą wąskiego ujęcia przedsiębiorczości. Niemniej jednak pomysł na prowadzenie działalności, umiejętność wykorzystania szans stwarzanych przez rynek i czynności związane z przygotowaniem przedsiębiorstwa do rozpoczęcia działalności wymagają posiadania cech przedsiębiorczych. Procedury administracyjno-prawne związane z założeniem własnej działalności gospodarczej nie są czynnościami skomplikowanymi, jednak wiążą się z daleko idącymi konsekwencjami wobec klientów, dostawców, urzędów i innych instytucji z bliskiego i dalszego otoczenia przedsiębiorstwa. Te zobowiązania wymagają uważnej i uczciwej pracy, która swoim wymiarem godzin może znacznie przekraczać przewidziany, dla osób zatrudnionych na umowę o pracę, czterdziestogodzinny tygodniowy wymiar pracy. Poświęcenie dużej ilości czasu na prowadzenie własnej działalności gospodarczej nie jest czynnikiem warunkującym jej powodzenie (Alstete, 2008; Mehralizadeh, Sajady, 2005; Singh, Rahman, 2013). Mimo większego znaczenia innych niż ciężka praca czynników warunkujących sukces przedsięwzięcia gospodarczego, bez niej żadne przedsięwzięcie nie ma szans powodzenia. Każdy innowacyjny pomysł, efektywna organizacja pracy, umiejętność podejmowania decyzji i ryzyka, wymagają trudnych i absorbujących czas czynności.

\section{Rola edukacji postaw przedsiębiorczych}

Znaczenie przedsiębiorczości we współczesnej gospodarce nakłada na społeczeństwo zmiany postaw i zwiększania swojej aktywności ekonomicznej. Zwiększa to wymagania stawiane społeczeństwu pod względem zdolności do adaptacji w rzeczywistości społeczno-gospodarczej. Automatyzacja i autonomizacja produkcji coraz powszechniej zastępują pracę ludzką. Można uznać, że świat wkroczył w rewolucję cyfrową, w rezultacie której rynek pracy może doznać szoku wynikającego z likwidacji wielu stanowisk pracy. Ważnym czynnikiem wspierającym te zmiany jest przedsiębiorcza edukacja, realizowana przez instytucje kształceniowe. Istnieje wiele opracowań zwracających uwagę na konieczność dostosowania programów kształcenia do potrzeb współczesnej gospodarki oraz wpływ, m.in. uczelni wyższych, na kształtowanie w społeczeństwie postaw przedsiębiorczych (Buchta, Jakubiak, 2014; Kwieciński, Młodzińska-Granek, 2014; Poznańska, 2014; Zimnoch, 2012). Najczęściej zwraca się uwagę na kompetencje z zakresu kreatywności, 
umiejętności rozwiązywania problemów i gotowości na nowe wyzwania (Rachwał, 2005; Strojny, 2007). Przedsiębiorca jako osoba powinien posiadać cechy wymienione przez S. Sudoła (Sudoł, 2006: 20-26):

- nieustanną chęć osiągania sukcesów,

- bycie niezależnym, samodzielnym,

- optymistyczne podejście do życia,

- umiejętność przyjmowania porażek i radzenia sobie z nimi,

- przeciętną gotowość do podejmowania działań obarczonych ryzykiem,

- chęć przewodzenia pozostałymi członkami zespołu,

- nieprzerwane wykazywanie się pomysłowością, podejmowanie innowacyjnych działań.

W opracowaniach naukowych badających postawy przedsiębiorcze studentów podejmowane są analizy skuteczności kształcenia przedsiębiorczego, rozumienia przedsiębiorczości oraz nasilenia postaw przedsiębiorczych. Wnioski z przeprowadzanych w tym zakresie badań wskazują, że studenci cechują się silnymi predyspozycjami przedsiębiorczymi (Łuczka, Rembiasz, 2016).

\section{Przedsiębiorczość pracownicza i studencka}

Głównym celem badań przedstawianych w niniejszym artykule jest analiza zachowań badanych jako potencjalnych pracowników oraz studentów, w odniesieniu do postaw przedsiębiorczych. Do realizacji celu badań postawiono następujące pytania badawcze:

1. Czy badani wykazują cechy przedsiębiorcze jako pracownicy?

2. Czy badani wykazują cechy przedsiębiorcze jako studenci?

3. Czy badani mają świadomość, jaki nakład pracy towarzyszy prowadzeniu własnej działalności gospodarczej?

Narzędziem badawczym wykorzystanym do zebrania danych był formularz ankietowy w formie online składający się z 10 pytań zamkniętych, z możliwością udzielenia jednej bądź wielu odpowiedzi (w zależności od pytania). Pytania zaproponowane respondentom nie odnosiły się wprost do kwestii związanych z prowadzeniem działalności gospodarczej, ale pośrednio im odpowiadały. Intencją autora było zweryfikowanie postaw studentów jako potencjalnych pracowników oraz ich zaangażowania w naukę na studiach wyższych. Konstruując narzędzie badawcze, przyjęto założenie, że postawy zadeklarowane przez badanych jako pracowników czy studentów można odnieść do zaangażowania w prowadzenie własnej działalności gospodarczej. W badaniu uczestniczyli studenci Wydziału Politologii Uniwersytetu Pedagogicznego w Krakowie, ankieta była wysłana do studentów studiów dziennych. Łącznie uzyskano 138 poprawnie wypełnionych formularzy. Zdecydowaną większość badanych stanowiły kobiety, których udział wyniósł $77,5 \%$. Niewiele ponad połowę badanych, 58,7\%, stanowili studenci kierunków nieekonomicznych. 16,7\% zadeklarowało, że pracuje zawodowo. Większość badanych (70,3\%) zadeklarowało chęć prowadzenia własnej działalności gospodarczej. Wielkość próby oraz charakter badań kwalifikuje je jako badania diagnostyczne. Zawężenie obszaru badań do studentów jednego wydziału uniemożliwia generalizację wyników badań i ilekroć w tekście pojawi się stwierdzenie odnoszące się do rezultatów badań, oznaczać to będzie wyniki dla studentów biorących udział w badaniu. 
W pierwszej części artykułu podniesiono kwestię pojęcia przedsiębiorczości i atrybutów przedsiębiorczości w odniesieniu do gospodarki, jednak zachowania przedsiębiorcze można adoptować do niemal każdej sfery życia. Studenci w trakcie procesu nauczania również muszą posiadać cechy przedsiębiorcze. Okres studiów to czas na zdobywanie wiedzy, wykonywanie prac domowych, pisanie projektów, działalność w kołach naukowych itd. Efektywny proces studiowania wymaga od studenta zaangażowania, dobrej organizacji, pasji, nowatorskiego myślenia, czyli ogólnie - przedsiębiorczości. W tabeli 1 zawarto dane odnoszące się do cech dobrego przedsiębiorcy, ale zmodyfikowane tak, aby odpowiadały obszarom związanym z procesem dydaktycznym w uczelni wyższej.

Tabela 1. Predyspozycje badanych studentów odnoszące się do cech przedsiębiorczych (w nawiasie odpowiadające im cechy przedsiębiorcze) ${ }^{1}$

\begin{tabular}{|l|c|c|c|c|c|}
\cline { 2 - 5 } \multicolumn{1}{l|}{} & $\begin{array}{c}\text { Zdecydowanie } \\
\text { tak }\end{array}$ & $\begin{array}{c}\text { Raczej } \\
\text { tak }\end{array}$ & $\begin{array}{c}\text { Trudno } \\
\text { powiedzieć }\end{array}$ & $\begin{array}{c}\text { Raczej } \\
\text { nie }\end{array}$ & $\begin{array}{c}\text { Zdecydowanie } \\
\text { nie }\end{array}$ \\
\hline $\begin{array}{l}\text { Nie potrzebuję motywacji } \\
\text { do nauki, uczę się } \\
\text { i zdobywam wiedzę } \\
\text { również poza uczelnią } \\
\text { (motywacja do działania) }\end{array}$ & $25,2 \%$ & $48,2 \%$ & $18,0 \%$ & $5,8 \%$ & $2,9 \%$ \\
\hline $\begin{array}{l}\text { Planuję wolny czas } \\
\text { i jest tam miejsce na } \\
\text { systematyczną naukę } \\
\text { (dobra organizacja) }\end{array}$ & $20,4 \%$ & $43,7 \%$ & $22,5 \%$ & $12,0 \%$ & $1,4 \%$ \\
\hline $\begin{array}{l}\text { Często zadaję pytania } \\
\text { wykładowcom i aktywnie } \\
\text { uczestniczę w zajęciach } \\
\text { (dociekliwość) }\end{array}$ & $7,1 \%$ & $32,1 \%$ & $33,6 \%$ & $22,9 \%$ & $4,3 \%$ \\
\hline $\begin{array}{l}\text { Nie przejmuję się, } \\
\text { gdy dostanę słabszą } \\
\text { ocenę, to motywuje } \\
\text { mnie do cięższej pracy } \\
\text { (umiejętność radzenia } \\
\text { sobie z porażką) }\end{array}$ & $15,8 \%$ & $36,0 \%$ & $20,9 \%$ & $20,9 \%$ & $6,5 \%$ \\
\hline $\begin{array}{l}\text { Staram się zgłębiać } \\
\text { wiedzę z zajęć } \\
\text { (samodyscyplina) }\end{array}$ & $25,2 \%$ & $50,3 \%$ & $16,1 \%$ & $8,4 \%$ & $0,0 \%$ \\
\hline $\begin{array}{l}\text { Mam dobry kontakt } \\
\text { z grupą i wykładowcami } \\
\text { (komunikatywnoś) }\end{array}$ & $22,5 \%$ & $60,6 \%$ & $13,4 \%$ & $3,5 \%$ & $0,0 \%$ \\
\hline $\begin{array}{l}\text { Jestem osobą oszczędną, } \\
\text { większość zakupów } \\
\text { jest przemyślana } \\
\text { (zapobiegawczość) }\end{array}$ & $32,2 \%$ & $38,4 \%$ & $17,1 \%$ & $9,6 \%$ & $2,7 \%$ \\
\hline $\begin{array}{l}\text { Lubię organizować } \\
\text { różne przedsięwzięcia } \\
\text { na uczelni i potrafię } \\
\text { zdobyć na to fundusze } \\
\text { (entuzjazm do działania) }\end{array}$ & $7,8 \%$ & $17,0 \%$ & $34,8 \%$ & $30,5 \%$ & $9,9 \%$ \\
\hline & & & & & \\
\hline
\end{tabular}

${ }^{1}$ Kolorem szarym zaznaczono dwie najczęściej występujące odpowiedzi. 


\begin{tabular}{|l|l|l|l|l|l|}
\hline $\begin{array}{l}\text { Wiem, jak postępować } \\
\text { z różnymi wykładowcami } \\
\text { w celu uzyskania lepszych } \\
\text { ocen i innych korzyści } \\
\text { (umiejętność radzenia } \\
\text { sobie w trudnych } \\
\text { sytuacjach) }\end{array}$ & $12,9 \%$ & $27,1 \%$ & $39,3 \%$ & $16,4 \%$ & $4,3 \%$ \\
\hline $\begin{array}{l}\text { W pracach zespołowych } \\
\text { zwykle przewodzę } \\
\text { grupie (zdolność } \\
\text { do przewodzenia) }\end{array}$ & $13,6 \%$ & $30,7 \%$ & $25,7 \%$ & $25,7 \%$ & $4,3 \%$ \\
\hline $\begin{array}{l}\text { Szybko zapominam } \\
\text { o porażkach i staram } \\
\text { się czerpać z nich naukę } \\
\text { (entuzjazm) }\end{array}$ & $18,3 \%$ & $38,0 \%$ & $23,2 \%$ & $14,1 \%$ & $6,3 \%$ \\
\hline
\end{tabular}

Źródło: opracowanie własne na podstawie wyników badań ankietowych $(\mathrm{N}=138)$

Na podstawie danych zawartych w tabeli 1 można stwierdzić, że badani studenci byli dobrze zmotywowani do zdobywania wiedzy, 48,2\% z nich uważało, że nie potrzebuje motywacji do nauki, a 25,2\%, że zdecydowanie jej nie potrzebuje. Spora część ankietowanych potrafi też zorganizować swój wolny czas i znaleźć w nim miejsce na systematyczną naukę, jednak 22,5\% osób miało trudność z określeniem, czy potrafi planować swój wolny czas. Mniej optymistycznie wygląda dociekliwość i aktywność studentów w trakcie zajęć najczęściej udzielaną odpowiedzią na pytanie dotyczące zadawania pytań wykładowcom była „trudno powiedzieć”. Takiej odpowiedzi udzieliło 33,6\% badanych, natomiast 22,9\% respondentów nie zadaje pytań w trakcie zajęć. Niekoniecznie oznacza to, że studenci nie zgłębiają wiedzy z zajęć, ponieważ zdecydowana większość studentów zadeklarowała, że stara się to robić. Mimo dość skromnej chęci do aktywności i zadawania pytań studenci deklarują, że mają dobry kontakt $\mathrm{z}$ otoczeniem - uznało tak $60,6 \%$ badanych, a $22,5 \%$ ankietowanych uznało, że zdecydowanie dobrze kontaktuje się z akademickim otoczeniem. Nieco gorzej wyglądają deklaracje badanych studentów dotyczące organizowania przedsięwzięć i zdobywania na nie funduszy - 34,8\% badanych zadeklarowało, że trudno na to odpowiedzieć, a 30,5\% przyznało, że nie lubi takiej aktywności.

Trudno jednoznacznie określić postawy przedsiębiorcze studentów względem studiów w uczelni wyższej - wielu ankietowanych miało trudności z określeniem swoich predyspozycji i aktywności. Największe pozytywne nasilenie cech dotyczyło obszarów chęci do nauki, komunikatywności i zapobiegliwości, co być może oznacza, że właściwe cechy są dopiero kształtowane.

Prowadzenie własnej działalności gospodarczej to wyzwanie, którego jednym z elementów jest poświęcenie dużej ilości czasu, szczególnie w początkowych latach działalności. Brak wolnego czasu jest jedną z wad pracy na własny rachunek. Standardowy czas pracy, przewidziany przez prawo w Polsce, to osiem godzin dziennie. Osoba przedsiębiorcza powinna potrafić tak zorganizować swój czas pracy, aby wykorzystać go maksymalnie efektywnie, jednak prowadzenie własnego przedsiębiorstwa wiąże się z pracą często przekraczającą „etatowy” wymiar godzin.

Badani studenci w większości, 57\% wskazań, deklarowali, że najbardziej preferują ośmiogodzinny dzień pracy, 23\% preferuje siedmiogodzinny, a 16\% - sześciogodzinny dzień pracy. Tylko $2 \%$ badanych zadeklarowało, że mogłoby pracować dziewięć godzin 
Rycina 1. Preferowany dzienny wymiar godzin pracy

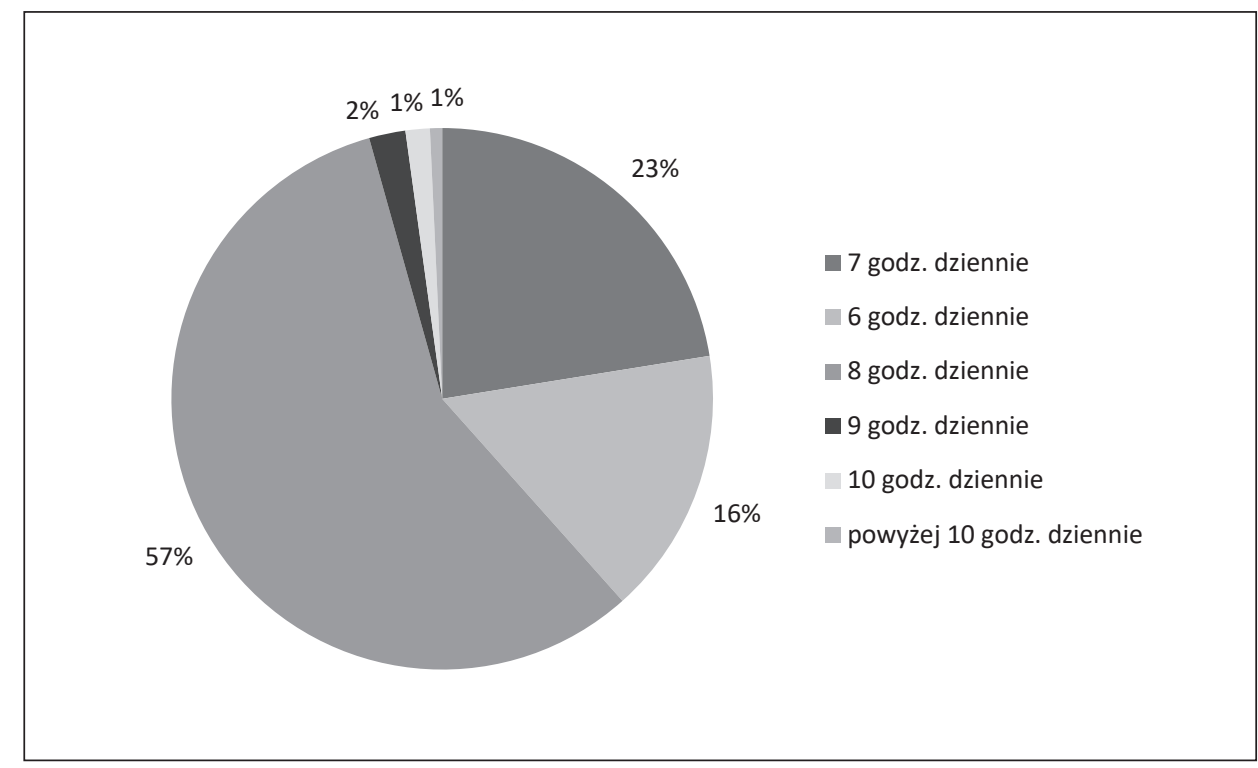

Źródło: opracowanie własne na podstawie wyników badań ankietowych $(\mathrm{N}=138)$

dziennie. Autor jest świadomy, że większość ludzi nie wykazuje preferencji do ponadwymiarowej pracy, dlatego powyższe odpowiedzi nie powinny zaskakiwać.

Wykonywanie zadań związanych z prowadzeniem działalności gospodarczej nie zawsze pozwala na planowanie urlopu, szczególnie w mniejszych przedsiębiorstwach, gdzie właściciel jest jednocześnie zarządcą. O ile elastyczny czas pracy jest często podawany jako zaleta, o tyle w rzeczywistości właściciel przedsiębiorstwa pracuje więcej dni w roku niż osoba zatrudniona na umowę o pracę. Pracownikowi etatowemu przysługuje 20-26 dni wolnego, przy czym największy wymiar urlopu przysługuje pracownikom pracującym dłużej niż 10 lat.

Studenci biorący udział w ankiecie w 35\% uznali, że wymiar urlopu w Polsce jest odpowiedni, ale aż 51\% uznało, że jest go za mało. Dodatkowo 13\% respondentów stwierdziło, że to zdecydowanie za mało.

Zakres obowiązków właściciela przedsiębiorstwa i odpowiedzialność wobec jego otoczenia sprawia, że taka osoba musi być niezwykle dyspozycyjna, co w rzeczywistości oznacza konieczność codziennego podpisywania dokumentów, autoryzowania płatności, podejmowania decyzji itd. W przypadku wystąpienia sytuacji uniemożliwiających wykonywanie pracy, takich jak choroba przy dużym uzależnieniu przedsiębiorstwa od właściciela, przedsiębiorstwo może stać się dysfunkcyjne. Studenci w pytaniu dotyczącym ich zachowania w czasie choroby w dużej liczbie odpowiedzi (48\%) uznali, że o ile dolegliwości zdrowotne nie byłyby ciężkie, to byliby w stanie normalnie pracować. Zaledwie $14 \%$ badanych uznało, że w trakcie choroby nie zamierza wykonywać żadnych obowiązków zawodowych. Oczywiście kwestia ta jest uregulowana przez Kodeks pracy - niedozwolone jest wykonywanie obowiązków służbowych w trakcie zwolnienia lekarskiego. Niemniej jednak badani studenci w $22 \%$ przypadków przyznali, że nawet będąc na zwolnieniu, mogliby wykonywać obowiązki zawodowe w domu. 
Rycina 2. Opinia dotycząca długości urlopu w Polsce

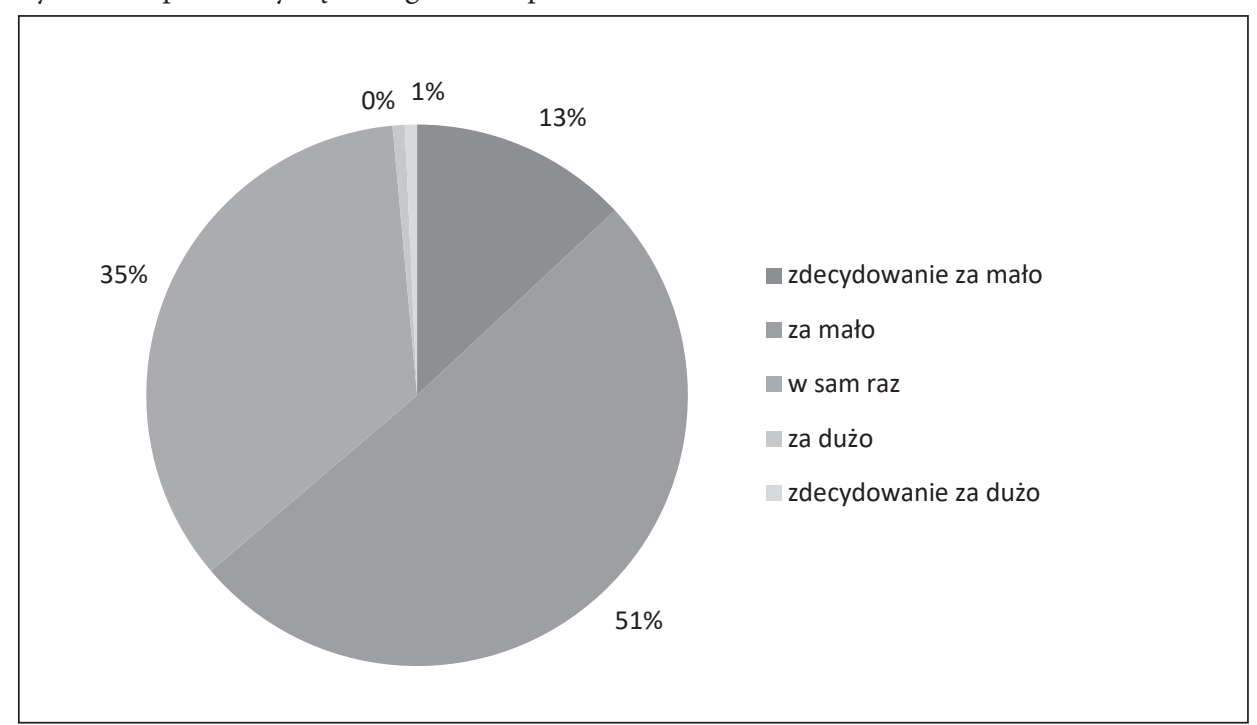

Źródło: opracowanie własne na podstawie wyników badań ankietowych $(\mathrm{N}=138)$

Rycina 3. Postępowanie badanych w czasie zdrowotnej niezdolności do pracy

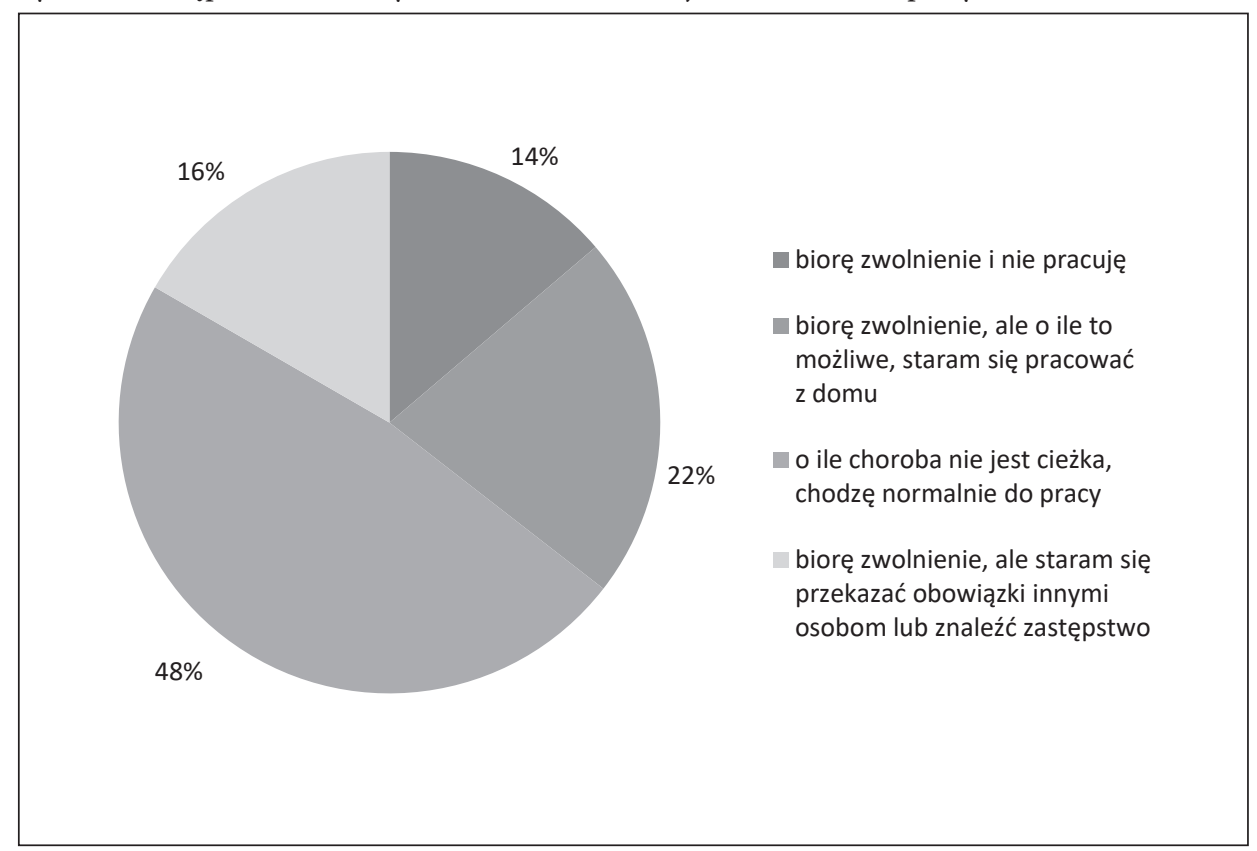

Źródło: opracowanie własne na podstawie wyników badań ankietowych $(\mathrm{N}=138)$ 
Rycina 4. Zachowanie pracownika w trudnej sytuacji pracodawcy

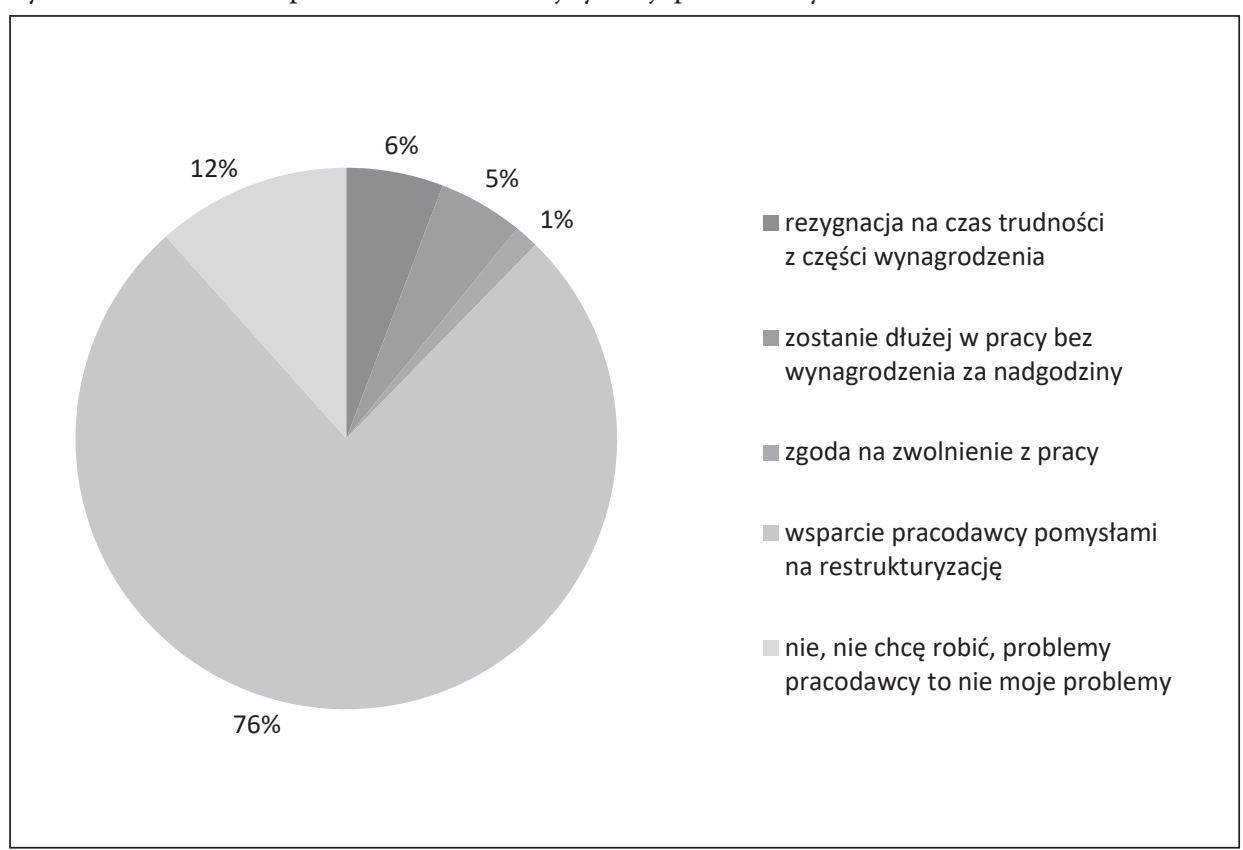

Źródło: opracowanie własne na podstawie wyników badań ankietowych $(\mathrm{N}=138)$

Podejmowanie wysiłków w zarządzaniu przedsiębiorstwem nie zawsze przynosi oczekiwane rezultaty. Dodatkowym utrudnieniem jest fakt, że nie zawsze sytuacja przedsiębiorstwa jest zależna od decydenta. Podejmowanie ryzyka i związana z nim odpowiedzialność jest codziennością przedsiębiorcy. Jak wynika z danych zamieszczonych na rycinie 4, badani studenci byliby w stanie wesprzeć pracodawcę pomysłami na restrukturyzację przedsiębiorstwa, gdyby znalazło się ono w trudnej sytuacji. Taką odpowiedź zaznaczyło $76 \%$ badanych. Niewielu spośród wszystkich ankietowanych (12\%) uznało, że w trudnej sytuacji przedsiębiorstwa nie zamierza podejmować żadnych działań, ponieważ są to problemy pracodawcy. Badani studenci nie chcieli, aby trudna sytuacja przedsiębiorstwa wpływała na ich sytuację materialną, ponieważ bardzo niewiele wskazań dotyczyło możliwości czasowej rezygnacji z części wynagrodzenia, zostawania dłużej w pracy czy zgody na zwolnienie z pracy.

Dwoje ankietowanych zaznaczyło w formularzu inną odpowiedź, dodając, że ich zachowanie będzie zależeć od dotychczasowej współpracy z pracodawcą.

Odpowiedzialność za przedsiębiorstwo dotyczy także jego sytuacji finansowej. W zależności od formy prawnej przedsiębiorstwa odpowiedzialność ta może być całkowita lub częściowa. Nawet w przypadku rozważnych decyzji przedsiębiorstwo mogą dotknąć trudności finansowe związane z zatorami płatniczymi, które wciąż są w Polsce zjawiskiem powszechnym. Takiej odpowiedzialności, a przynajmniej - w takim wymiarze, nie ponosi pracownik, jednak jego postawa w sytuacji braku płynności finansowej przedsiębiorstwa może znacząco wpłynąć na przyszłą sytuację przedsiębiorstwa. W pytaniu odnoszącym się do sytuacji, w której występują trudności z płatnościami wynagrodzenia, ankietowani w 41,1\% odpowiedzi uznali, że w przypadku opóźnień w zapłacie wynagrodzenia będą 
Rycina 5. Zachowanie badanych w przypadku opóźnienia wypłaty wynagrodzenia
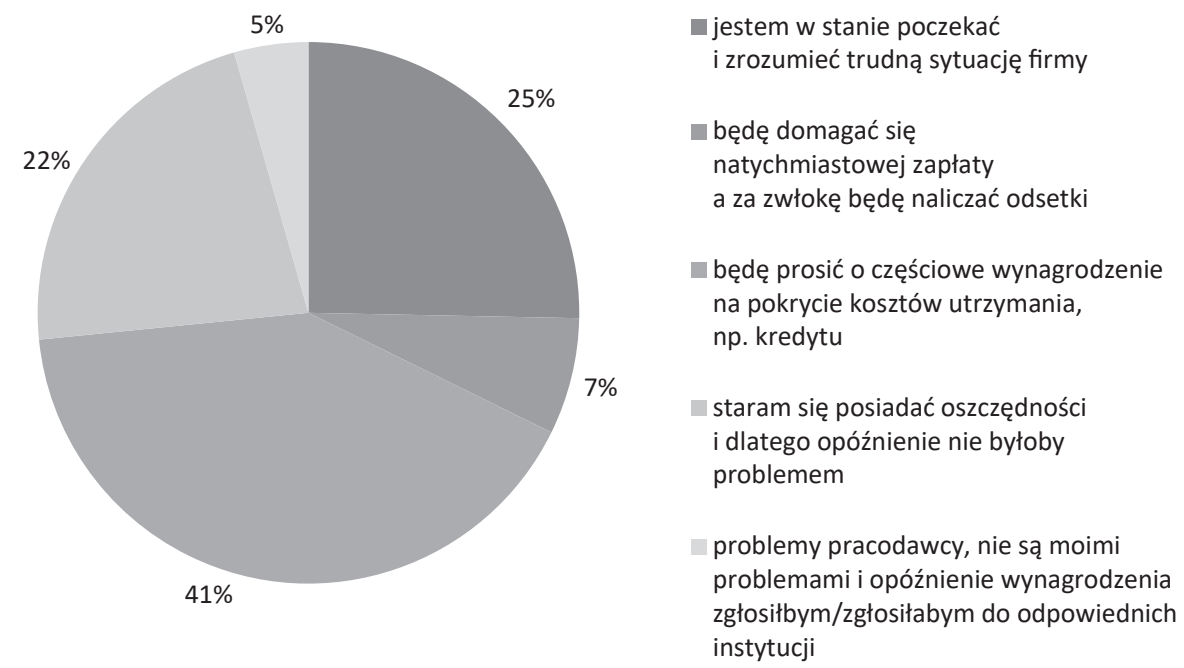

Źródło: opracowanie własne na podstawie wyników badań ankietowych $(\mathrm{N}=138)$

prosić o częściową zapłatę pozwalającą pokryć stałe koszty gospodarstwa domowego. Spora część badanych $(22,2 \%)$ uznała, że stara się posiadać oszczędności i opóźnienie $\mathrm{w}$ wypłacie wynagrodzenia nie stanowiłoby problemu.

Bardzo niewielu ankietowanych (7\%) uznało, że będzie się domagać wynagrodzenia, a nawet zażąda zapłaty odsetek za zwłokę.

Przedsiębiorca to także osoba, która powinna się cechować zdolnościami przywódczymi. Wspierają one zarządzanie zasobami ludzkimi w przedsiębiorstwie. Zdolności takie są przydatne nie tylko w przypadku prowadzenia własnej działalności gospodarczej, ale także w przypadku pełnienia funkcji kierowniczych w strukturze przedsiębiorstwa. Odpowiedzialność na takim stanowisku jest większa, gdyż ponosimy również konsekwencje za niepoprawne wykonanie zadań przez podległe nam osoby. Stanowisko takie cieszy się większym uznaniem społecznym i praca na nim może przynosić dużą satysfakcję, gdy realizowane przedsięwzięcia kończą się sukcesem. Tylko $11 \% \mathrm{z}$ ankietowanych przyznało, że byłoby w stanie wziąć odpowiedzialność za funkcjonowanie całego przedsiębiorstwa, a aż $41 \%$ mogłoby odpowiadać za konkretny dział w przedsiębiorstwie.

Część badanych, tj. 18\%, procesowo potraktowała zarządzanie zasobami ludzkimi i mogłaby wziąć odpowiedzialność za określony projekt realizowany przez firmę. Natomiast $30 \%$ respondentów uznało, że chce odpowiadać tylko za swoje stanowisko i za wykonywanie swoich obowiązków. 
Rycina 6. Preferowana odpowiedzialność na stanowisku pracy

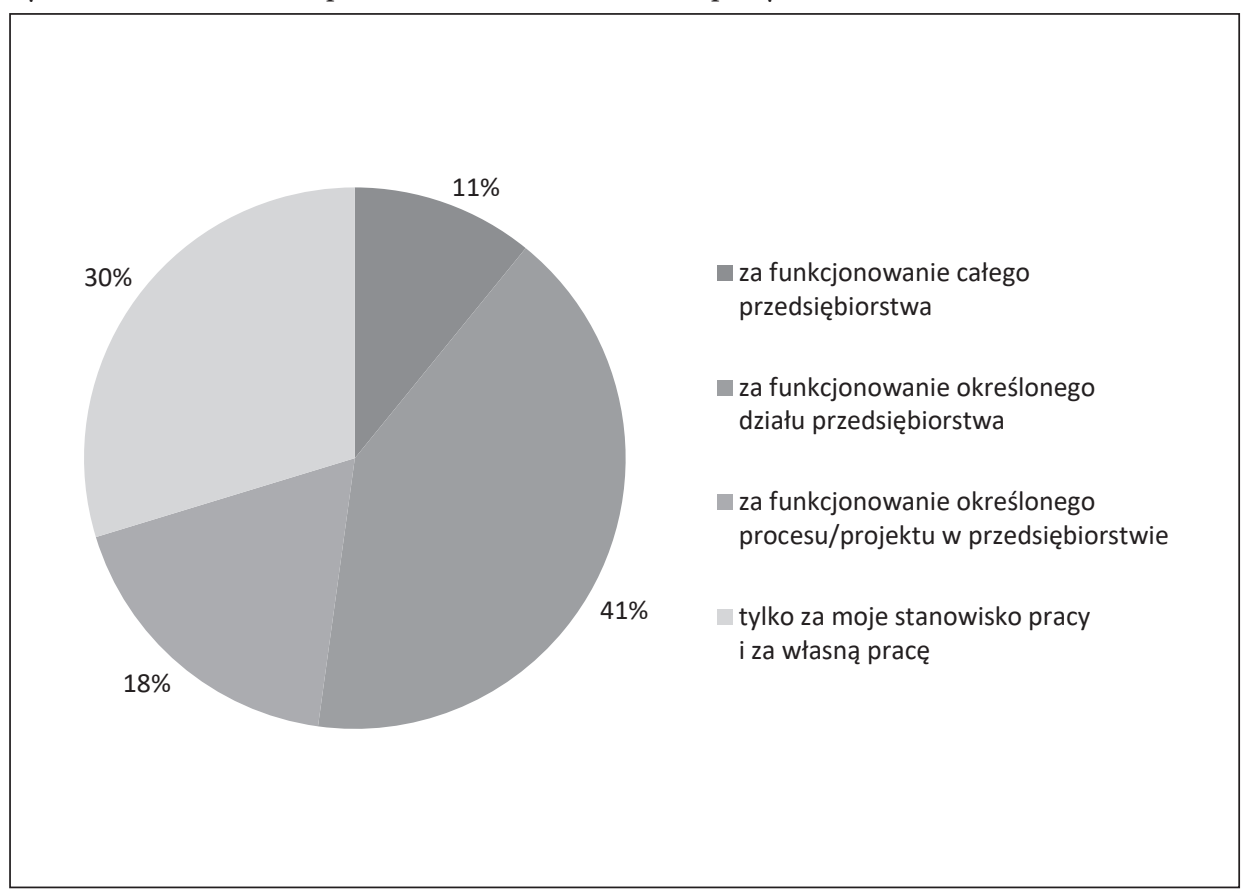

Źródło: opracowanie własne na podstawie wyników badań ankietowych $(\mathrm{N}=138)$

\section{Podsumowanie i rekomendacje}

Przedstawione powyżej wyniki badań mają pewne ograniczenia wynikające z niewielkiej liczby badanych, wąskiego obszaru badań, a także z wybiórczego doboru cech przedsiębiorczych. W rezultacie na ich podstawie można jedynie częściowo odpowiedzieć na postawione w pracy pytania badawcze. Z pewnością studenci niejednoznacznie byli w stanie określić swój poziom pracowniczej odpowiedzialności, można także uznać, że przywiązują dużą wagę do wartości czasu wolnego, są natomiast skłonni do poświęceń w trakcie choroby. W odniesieniu do procesu studiowania studenci wysoko ocenili swoją motywację i zaangażowanie w naukę oraz komunikatywność, chociaż słabo ocenili swoją aktywność w trakcie zajęć. Biorąc pod uwagę deklaracje badanych dotyczące chęci prowadzenia działalności gospodarczej i oceny związane z preferowanym czasem pracy, a także wartość czasu wolnego, można uznać, że mają niską świadomość prowadzenia działalności gospodarczej, która w dużej mierze polega na ciężkiej i odpowiedzialnej pracy. Sukces i korzyści wynikające z takiej formy pracy są dostępne dopiero po wielu latach wyrzeczeń.

W dyskusji dotyczącej prowadzania działalności gospodarczej często przywiązuje się wagę do procesu rejestracji przedsiębiorstwa oraz do pozytywnych aspektów związanych z posiadaniem własnej firmy. Propagowanie działalności na własny rachunek ma z pewnością pozytywny wpływ na gospodarkę i konkurencyjność, ale oprócz wszystkich pozytywnych aspektów należy jasno naświetlać także te związane z odpowiedzialnością i trudnymi wyzwaniami, które pojawiają się przed przedsiębiorcami. 
Literatura

References

Alstete, J.W. (2008). Aspects of entrepreneurial success. Journal of Small Business and Enterprise Development, 15(3), 584-594. Pozyskano z: https://www.emeraldinsight.com/DOI/abs/10.1108/14626000810892364?fullSc=1\&journalCode=jsbed

Buchta, K., Jakubiak, M. (2014). Determinanty postaw przedsiębiorczych jako element innowacyjności. Zeszyty Naukowe WSEI. Ekonomia, 9(2), 167-179.

Czarnecka, A., Kłodziński, M. (2010). Przedsiębiorczość pozarolnicza na obszarach wiejskich regionów zielonych płuc. Zagadnienia Ekonomiki Rolnej, 3, 63-78.

Gartner, W.B. (1990). What are we talking about when we talk about entrepreneurship?. Journal of Business Venturing, 5, 15-28.

Guerrero, M., Cunningham, J.A., Urbano, D. (2014). Economic impact of entrepreneurial universities' activities: An exploratory study of the United Kingdom. Research Policy, 44(3), 748-764.

Kwieciński, L., Młodzińska-Granek, A. (2014). Academic Entrepreneurship in the Humanities and Social Sciences: Research Conducted among Students of Wroclaw University. Horyzonty Wychowania, 13(26).

Łuczka, T., Rembiasz, M. (2016). Badanie postaw przedsiębiorczych studentów - wybrane aspekty teoretyczne i empiryczne. Horyzonty Wychowania, 15(34), 27-47. doi: 10.17399/HW.2016.153402

Maciejewski, W., Faron, A. (2014). Edukacja ekonomiczna i przedsiębiorcza a postawy przedsiębiorcze osób bezrobotnych. Przedsiębiorczość i Zarządzanie, XV, 10(2), 69-82.

Mehralizadeh, Y., Sajady, S.H. (2005; 2018, 30 kwietnia). A study of factors related to successful and failure of entrepreneurs of small industrial business with emphasis on their level of education and training. Pozyskano z: http://www.leeds.ac.uk/educol/documents/143150.htm

Płaziak, M., Rachwał, T. (2015). „Przedsiębiorczy region” - zarys koncepcji w świetle analizy roli przedsiębiorczości w krajowej strategii rozwoju regionalnego. Przedsiębiorczość - Edukacja, 11, 37-49.

Poznańska, K. (2014). Przedsiębiorczość akademicka - cechy i znaczenie w gospodarce światowej i polskiej. W: T. Kraśnicka (red.), Innowacyjność wspótczesnych organizacji. Kierunki i wyniki badań [II]. Katowice: Uniwersytet Ekonomiczny, 164-172.

Rachwał, T. (2005). Kształtowanie postaw u uczniów na lekcjach podstaw przedsiębiorczości. Przedsiębiorczość - Edukacja, 1, 137-144.

Singh, H.R., Rahman, H. (2013). Traits of successful Entrepreneurs. International Journal of Scientific Research, 2(11), 292-294. Pozyskano z: https://www.researchgate.net/publication/273445209_ Traits_of_Successful_Entrepreneurs

Stel, A., Carree, M., Thurik, R. (2005). The Effect of Entrepreneurial Activity on National Economic Growth. Small Business Economics, 24(3), 311-321. Pozyskano z: https://link.springer.com/article/10.1007/s11187-005-1996-6

Strojny, J. (2007). Kształtowanie postawy przedsiębiorczej - procesy socjalizacji i autokreacji. W: P. Wachowiak, M. Dąbrowski, B. Majewski (red.), Ksztattowanie postaw przedsiębiorczych a edukacja ekonomiczna. Warszawa: FPiAKE, 205-211.

Sudoł, S. (2006) Przedsiębiorstwo. Podstawy nauki o przedsiębiorstwie. Zarządzanie przedsiębiorstwem. Warszawa: Polskie Wydawnictwo Ekonomiczne.

Wach, K. (2015). Przedsiębiorczość jako czynnik rozwoju społeczno-gospodarczego: przegląd literatury. Przedsiębiorczość - Edukacja, 11, 24-36.

Zimnoch, K. (2012). Edukacja jako priorytet polityki społecznej i najważniejszy czynnik rozwoju społecznego. Zeszyty Naukowe Wydziałowe Uniwersytetu Ekonomicznego w Katowicach, 53-62.

Zioło, Z. (2016). Przedsiębiorczość w rozwoju układów lokalnych. Przedsiębiorczość - Edukacja, 12, 6-17.

Zioło, Z. (2012). Kształtowanie wiejskich rynków pracy na przykładzie wybranych województw. Studia Komitetu Przestrzennego Zagospodarowania Kraju PAN, CXLV, 106-141. 
Wojciech Maciejewski, dr, adiunkt w Katedrze Ekonomii i Polityki Gospodarczej Uniwersytetu Pedagogicznego im. Komisji Edukacji Narodowej w Krakowie. Członek zarządu Stowarzyszenia Naooka. Jego zainteresowania badawcze dotyczą obszarów przedsiębiorczości, cech przedsiębiorczych, problematyki decyzji oraz czynników wpływających na powodzenie przedsięwzięć gospodarczych.

Wojciech Maciejewski, PhD, assistant professor in the Department of Economics and Economic Policy of the Pedagogical University of Cracow. Member of the board of the Naooka Association. Research interests concern the areas of entrepreneurship, entrepreneurial features, decision issues and factors affecting the success of business ventures.

ORCID: 0000-0002-5761-0489

\section{Adres/Address:}

Uniwersytet Pedagogiczny im. Komisji Edukacji Narodowej

Instytut Prawa Administracji i Ekonomii

ul. Podchorążych 2

30-084 Kraków

e-mail: wmaciejewski@up.krakow.pl 